IZA DP No. 8424

Introduction to $A$ Theory of the Allocation of Time by Gary Becker

James Heckman

August 2014 


\title{
Introduction to A Theory of the Allocation of Time by Gary Becker
}

\author{
James Heckman \\ University of Chicago, \\ American Bar Foundation and IZA
}

Discussion Paper No. 8424

August 2014

IZA

P.O. Box 7240

53072 Bonn

Germany

Phone: +49-228-3894-0

Fax: +49-228-3894-180

E-mail: iza@iza.org

\begin{abstract}
Any opinions expressed here are those of the author(s) and not those of IZA. Research published in this series may include views on policy, but the institute itself takes no institutional policy positions. The IZA research network is committed to the IZA Guiding Principles of Research Integrity.

The Institute for the Study of Labor (IZA) in Bonn is a local and virtual international research center and a place of communication between science, politics and business. IZA is an independent nonprofit organization supported by Deutsche Post Foundation. The center is associated with the University of Bonn and offers a stimulating research environment through its international network, workshops and conferences, data service, project support, research visits and doctoral program. IZA engages in (i) original and internationally competitive research in all fields of labor economics, (ii) development of policy concepts, and (iii) dissemination of research results and concepts to the interested public.
\end{abstract}

IZA Discussion Papers often represent preliminary work and are circulated to encourage discussion. Citation of such a paper should account for its provisional character. A revised version may be available directly from the author. 


\title{
ABSTRACT \\ Introduction to A Theory of the Allocation of Time by Gary Becker
}

\begin{abstract}
Gary Becker's classic study, A Theory of the Allocation of Time, laid the analytical foundations for the study of household production and the allocation of time within the household. The analytical framework of household production theory developed in this paper remained a pillar of his later work on the economics of the family and the economics of nonmarket activities more generally. Becker provided a formal model of households producing outputs like food, children, and housing that bundled goods and time. Becker's great contribution was to apply the model to interpret a broad array of empirical phenomena. Becker's framework allowed for a deeper understanding of the mechanisms of consumer choice, and interpretation of income and substitution effects. Its continuing relevance in empirical economics is a testimony to its power.
\end{abstract}

JEL Classification: B31, D13, J24

Keywords: household production, economics of the family, empirical economics

Corresponding author:

James Heckman

Department of Economics

University of Chicago

1126 E. 59th Street

Chicago IL 66037

USA

E-mail: jjh@uchicago.edu

\footnotetext{
* Gary Becker was born December 2, 1930 and died May 2, 2014.

The research was supported in part by the American Bar Foundation, the Pritzker Children's Initiative, the Buffett Early Childhood Fund, NIH grants NICHD R37HD065072 and R01HD54702, an anonymous funder, a European Research Council grant (DEVHEALTH 269874), and a grant from the Institute for New Economic Thinking (INET) to the Human Capital and Economic Opportunity Global Working Group (HCEO) an initiative of the Becker Friedman Institute for Research in Economics (BFI). I thank Reuben Gronau, John Pencavel, Robert Pollak and Frederic Vermeulen for comments on drafts of this paper. The views expressed here are those of the author and not necessarily those of the funders or persons named here. This paper is forthcoming in the Economic Journal.
} 
Gary Becker's classic study, A Theory of the Allocation of Time, laid the analytical foundations for the study of household production and the allocation of time within the household. It spawned a large literature and continues to influence economics and other social sciences.

The paper was written when Becker was in his mid 30s, teaching at Columbia University and conducting research at the National Bureau of Economic Research, then headquartered in New York. Over the period 1958-1970, Becker, along with Jacob Mincer, organized the legendary Columbia Labor Economics Workshop. Becker, Mincer, and their students applied price theory to study the economics of fertility, labor supply, income inequality, education, on-the-job training, crime and punishment and the theory of irrational behavior, among other topics. The interplay between theory and data was the hallmark of that group. From this crucible emerged the modern theory of human capital (Becker, 1964, 1975) and important components of the modern economics of the family that were distilled and extended in Becker's classic A Treatise on the Family (1981, enlarged in 1991). A generation of productive and influential scholars was trained at Columbia during this period. ${ }^{1}$

In his introduction to this paper, Becker discusses the body of research on the economics of time that was being conducted at Columbia, to which he contributed and from which he had drawn. This paper is the analytical synthesis of a body of ideas developed in that intense intellectual climate.

Many scholars have tried to disentangle the contributions of Jacob Mincer from those of Gary Becker during the period of their synergistic collaboration. Attempts to do so miss the highly interactive and mutually supportive intellectual environment of the Columbia group and the ability of Becker to create clean analytical insights from diverse bodies of empirical work and to stimulate all around him.

\footnotetext{
${ }^{1}$ See Heckman (2014).
} 


\section{Some Background on This Article}

Prior to the work of Becker, the household had a shadowy place in analytical economics. Wesley Clair Mitchell (1912) wrote about the "backward art of spending money" and compared the efficiency of firms in producing goods for the market to the inefficiency of households in producing domestic services. Kuznets (1934) lamented that GNP accounts omitted important components of household production..$^{2}$ Margaret Reid (1934) wrote a textbook on home production aimed at students of home economics. It offered practical advice, sketched some analytical principles, and offered interesting speculation about the future of the household and role of women 3

It was not until the work of Becker (1965) that economists began to formally model households as engaged in activities producing outputs like food, children, and housing (the $Z_{i}$ for commodity $i$ in his paper) that bundled goods and time. The household consumed these commodities as the direct objects of utility $\left.\right|^{4}$ The outputs of the activities were produced by distinct inputs $5^{5}$ The commodities were associated with consumption in different time periods (e.g., Ghez and Becker, 1975) or production of different activities (meals, health, housing, child rearing) as in Becker (1965); Grossman (1972a b); Michael (1972, 1973), and Muth (1966) $!^{6}$ Becker and Mincer breathed empirical life into these models and spawned a large literature (see, e.g., Gronau, 1970, 1977, 1986, 1997, 2008; Grossman, 1972a, b; Juster and Stafford, 1985, 1991; Leibowitz, 1974; Michael, 1973, 1974; Michael and Becker, 1973;

\footnotetext{
${ }^{2}$ See Bridgman et al. (2012) for a recent discussion of household production in national accounts. Nordhaus and Tobin (1973) created estimates of nonmarket production to supplement GNP accounts. See also the National Research Council (2005) for chapter "Home Production," and Stiglitz et al. (2009).

${ }^{3}$ Gary Becker checked out her book from the University of Chicago Library in 1956.

${ }_{4}^{4}$ Muth (1966) modeled household production in this fashion but did not focus on the crucial role of time or on the range of phenomena analyzed by Becker. Gorman (1956, 1980) and Lancaster (1966, 1971) analyzed the demand for characteristics produced by goods. Characteristics in that model play a role analogous to commodities in Becker's model. As in Becker's model, goods produce outputs that are valued in final consumption. In Becker's model, goods are allocated to produce a single commodity. In the GormanLancaster model, the same market goods can produce multiple characteristics (commodities) so there is jointness, which is ruled out in Becker's model. See Pollak and Wachter (1975) and Gronau (1986).

${ }^{5}$ Later work incorporated joint production (Pollak and Wachter, 1975).

${ }^{6}$ Closely related analytically was the work on separability in preferences studied by Strotz (1957) and Gorman (1959). See also Green (1964) and Blackorby et al. (1978).
} 
Pollak, 2003; Rosenzweig and Schultz, 1983).

The Becker-Mincer research on human capital (Becker, 1962, 1964, 1975; Mincer, 1958, 1962a, 1974) emphasized the importance of time foregone from earnings as the primary cost of education and job training, far more important than costs arising from tuition or fees. In other work, Mincer (1962b, 1963) made a major contribution to empirical research on the labor supply of women by isolating the effects of wages (the price of time) from pure income effects, explaining both the cross-section and time series of married female labor supply 7

While Lionel Robbins (1930) had previously distinguished income effects from substitution effects in labor supply, the empirical literature on female labor supply had not made this distinction. Clarence Long (1958), in an extensive empirical study, emphasized the role of consumer durables in releasing female time from housework for market uses, but did not study the effects of wages on labor supply $\left.\right|^{8}$ In a similar spirit, Becker's (1960) early work on fertility focused on income effects and did not discuss the importance of female time and its price in explaining fertility 9 It was Mincer who first emphasized the role of the rise in the wage of women as a primary force explaining the growth of female labor supply.

Mincer (1962b) introduced another feature of household production that is formalized in Becker (1965). Mincer claimed that the multiple uses of nonmarket time (in child care and other household activities) produced a greater wage elasticity for women than for men because they faced more margins of substitution. While formally this argument is incorrect, the intuition behind it is powerful and continues to shape thinking about female labor supply 10

\footnotetext{
7 Mincer (1963) analyzed the bias in estimating pure income effects when the price of time was omitted from consumer demand analyses.

8 Greenwood et al. (2005) formalize Long's idea in a general equilibrium setting.

${ }^{9}$ However, he hints at the role of the price of time in his footnote 8 .

${ }^{10}$ See Heckman (1988).
} 


\section{The Becker Model}

The household is assumed to produce and consume a vector of commodities $Z=\left(Z_{i}\right), i=$ $1, \ldots, I$. These commodities are associated with different levels of activities performed by the household (e.g., consumption of food, child-rearing, leisure activities), including leisure on the job.11 Utility is a function of these commodities:

$$
U\left(Z_{1}, \cdots, Z_{I}\right)
$$

where

$$
Z_{i}=f^{(i)}\left(X_{i}, T_{i}\right), \quad i=1, \ldots, I
$$

$X_{i}$ is a vector of goods used to produce $Z_{i}$ and $T_{i}$ is time (usually assumed scalar but allowed to be a vector in Becker, 1965) 12 The price of $Z_{i}$ depends on the prices of its components. Assuming that each $f^{(i)}$ is homogeneous of degree 1, one can construct a scale-invariant price index $\pi_{i}$ for each commodity.

The household faces both time and traditional budget constraints. Using elementary algebra, Becker shows that under his assumptions the household effectively faces one constraint ${ }^{13}$ Under the assumption that $T_{i}$ is scalar, and that the price of time is $w$ across all uses, the maximum amount of income that the person can earn is Full Income $B=w T+V$ where $T=\sum T_{i}$ and $\mathrm{V}$ is the amount of unearned income accruing to the household. The $Z_{i}$ encompass all activities in which time can be used (including the consumption of leisure on the job) and

\footnotetext{
${ }^{11}$ See Juster and Stafford (1985), Aguiar and Hurst (2007), and Aguiar et al. (2012).

${ }^{12}$ See Becker (2007a) for one exposition of this model.

${ }^{13}$ See Heckman (1988) for an analysis of households facing multiple constraints.
} 


$$
\sum_{i=1}^{I} \pi_{i} Z_{i}=w T+V=B
$$

The household is assumed to maximize (1) subject to (2) and (3). The demands for inputs $X_{i}, T_{i}$ are derived from the demands for $Z_{i}$. The responsiveness of the demands for different activities in response to changes in the prices of goods and time depends, in part, on the time and goods intensities in producing the commodities. Becker goes on to develop a more general analysis where the marginal cost of time varies across activities.

Becker's model of commodity demand is an instance of Terence Gorman's general separability analysis (Gorman, 1959) where $U$ is weakly separable in the arguments producing the $Z_{i}$, and the $f^{(i)}$ are homogeneous of degree $1{ }^{14}$ Under homogeneous weak separability, consumer decision making can be characterized by a two stage budgeting process. Agents allocate budgets $E_{i}$ to each commodity $i$, based on the price index $\pi_{i}$ and in a second stage maximize each $Z_{i}$ subject to these allocations determined from the first stage to determine $X_{i}$ and $T_{i}$. (See Strotz, 1957 and Gorman, 1959), ${ }^{15}$ Pollak and Wachter (1975) present a definitive analysis of the limitations of the Becker model when the assumption of homogeneous separability is relaxed and when joint production is considered $\sqrt{16}$ See also the discussion in Gronau (1977, 1986).$^{17}$

\section{$3 \quad$ Its Influence}

Although others had developed analytical frameworks with similar features, Becker's great contribution was to apply the model to interpret a broad array of empirical phenomena and to inspire the generations that followed in his wake to investigate the economics of

\footnotetext{
${ }^{14}$ However, Gorman does not specifically analyze time or allow marginal prices to vary across activities.

${ }^{15}$ See Green (1964) and Blackorby et al. (1978) for discussions of this literature.

${ }^{16}$ They stress a key limitation that time spent in producing commodities is not valued in itself. Thus, in producing children, the time spent in producing them is not valued in itself. For a discussion of estimation of non-separable technologies see Pollak and Wales (1987).

${ }^{17}$ Gronau (1977) distinguishes between the non-utility bearing use of time in producing goods (work at home) from use of time in producing utility.
} 
home production. The concept of nonmarket production of human capital (Ben-Porath, 1967), children (Becker and Lewis, 1973; Willis, 1973), health (Becker, 2007b; Grossman, 1972a b), the value of life (Viscusi and Aldy, 2003), the production of child quality (Cunha and Heckman, 2007; Leibowitz, 1974), transportation (Gronau, 1970), the consumption of leisure on-the-job Aguiar and Hurst, 2007; Aguiar et al., 2012; Juster and Stafford, 1985) are just a few of the numerous applications of these ideas 18 Becker's paper also stimulated the collection of data on time use in household production (see e.g. Aguiar et al., 2012; Juster and Stafford, 1985, 1991).

\section{Theory of Labor Supply}

When Becker's paper was initially published, many scholars noted that under the assumption that the price of time was uniform across alternative uses, application of Hicks' composite commodity theorem (Hicks, 1939) leads back to the elementary analysis of labor supply by Lionel Robbins. All non-market time can be aggregated into a single composite "leisure."19 There was no need for household production theory to analyze the supply of labor to the market.

While formally true, this commentary misses several key points. First, Becker analyzed a situation in which the marginal prices of time may differ in different uses ${ }^{20}$ Second, his paper reconciled the Long (1958) interpretation of the growth of the labor supply of women as arising from a shift in the supply of labor through the introduction of labor-saving consumer durables, and the model favored by Mincer (1962b) that shifts in the demand for female labor led to higher wages and higher labor supply.21

More generally, Becker's framework allowed for a deeper understanding of the mechanisms of consumer choice, and interpretation of income and substitution effects. Its continuing

\footnotetext{
18 Gronau (1997) gives a useful survey of the applications of the model in both micro and macro economics. ${ }^{19}$ See, e.g., Heckman (1988).

${ }^{20}$ For example, overtime pay, weekend pay and nighttime pay may differ.

${ }^{21}$ See Greenwood et al. (2005).
} 
relevance in empirical economics is a testimony to its power.

\section{Developments After This Paper}

Becker was near the beginning of his long and productive career when he wrote this paper. He elaborated the model in his later work. However, the analytical framework of household production theory developed in this paper remained a pillar of his later work on the economics of the family and the economics of nonmarket activities more generally.

He devotes only one paragraph of this paper to the idea that household members might specialize in the production of commodities. He developed it much further in Becker 1973 , 1974) and Becker (1981, 1991). There he developed theories of household formation and marital sorting and investigated the consequences of intrahousehold specialization in tasks for life cycle earnings and productivity. ${ }^{22}$ For a recent exposition of the development of these themes, see Browning et al. (2014).

\footnotetext{
${ }^{22}$ Pollak (2013) presents an illuminating discussion of Becker's work on specialization in the household.
} 


\section{References}

Aguiar, M. and E. Hurst (2007). Measuring trends in leisure: The allocation of time over five decades. Quarterly Journal of Economics 122(3), 969-1006.

Aguiar, M., E. Hurst, and L. Karabarbounis (2012). Recent developments in the economics of time use. Annual Review of Economics 4, 373-397.

Becker, G. S. (1960). An economic analysis of fertility. In G. B. Roberts (Ed.), Demographic and Economic Change in Developed Countries, pp. 209-240. New York, NY: Columbia University Press. National Bureau of Economic Research, http://www.nber.org/chapters/c2387.

Becker, G. S. (1962). Irrational behavior and economic theory. Journal of Political Economy $70,1-13$.

Becker, G. S. (1964). Human Capital: A Theoretical and Empirical Analysis, With Special Reference to Education. New York: National Bureau of Economic Research.

Becker, G. S. (1965). A theory of the allocation of time. The Economic Journal 75(299), $493-517$.

Becker, G. S. (1973, July). A theory of marriage: Part I. Journal of Political Economy 81(4), $813-846$.

Becker, G. S. (1974). A theory of social interactions. Journal of Political Economy 82(6), 1063-1093.

Becker, G. S. (1975). Human capital and the personal distribution of income: An analytical approach. In Human capital: a theoretical and empirical analysis, with special reference to education (2 ed.). New York: National Bureau of Economic Research.

Becker, G. S. (1981). A Treatise on the Family. Cambridge, Mass.: Harvard University Press. 
Becker, G. S. (1991). A Treatise on the Family (Enlarged ed.). Cambridge, MA: Harvard University Press.

Becker, G. S. (2007a). Economic Theory. New Brunswick, NJ: Transaction Publishers.

Becker, G. S. (2007b). Health as human capital: synthesis and extensions. Oxford Economic Papers 59(3), 379-410.

Becker, G. S. and H. G. Lewis (1973, March). On the interaction between the quantity and quality of children. Journal of Political Economy 81(2, Supplement), S279-S288.

Ben-Porath, Y. (1967, August). The production of human capital and the life cycle of earnings. Journal of Political Economy 75(4, Part 1), 352-365.

Blackorby, C., D. Primont, and R. R. Russell (1978). Duality, Separability, and Functional Structure: Theory and Economic Applications. Dynamic Economics. Amsterdam: Elsevier North-Holland.

Bridgman, B., A. Dugan, M. Lal, and M. Osborne (2012). Accounting for household production in the national accounts,19652010. Survey of Current Business 92(5), 23-36.

Browning, M., P. A. Chiappori, and Y. Weiss (2014). Family Economics. Cambridge, UK: Cambridge University Press.

Cunha, F. and J. J. Heckman (2007, May). The technology of skill formation. American Economic Review 97(2), 31-47.

Ghez, G. R. and G. S. Becker (1975). The Allocation of Time and Goods over the Life Cycle. New York: National Bureau of Economic Research.

Gorman, W. M. (1956, November). The demand for related goods. Technical Report Journal Paper No. J3129, Iowa Agricultural Experiment Station. 
Gorman, W. M. (1959, July). Separable utility and aggregation. Econometrica 27(3), 469481.

Gorman, W. M. (1980, October). A possible procedure for analysing quality differentials in the egg market. Review of Economic Studies 47(5), 843-856.

Green, H. A. J. (1964). Aggregation in Economic Analysis; an Introductory Survey. Princeton, NJ: Princeton University Press.

Greenwood, J., A. Seshadri, and M. Yorukoglu (2005). Engines of liberation. The Review of Economic Studies 72(1), 109-133.

Gronau, R. (1970, May). The Value of Time in Passenger Transportation: The Demand for Air Travel. NBER Books, National Bureau of Economic Research, Inc.

Gronau, R. (1977, December). Leisure, home production and work-'the theory of the allocation of time' revisited. Journal of Political Economy 85(6), 1099-1123.

Gronau, R. (1986). Home production-a survey. In O. Ashenfelter and R. Layard (Eds.), Handbook of Labor Economics, Volume 1, pp. 273-304. Amsterdam: Elsevier Science Publishers.

Gronau, R. (1997, April). The theory of home production: The past ten years. Journal of Labor Economics 15(2), 197-205.

Gronau, R. (2008). Household production and public goods. In S. N. Durlauf and L. E. Blume (Eds.), The New Palgrave Dictionary of Economics (2 ed.). New York, NY: Stockton Press.

Grossman, M. (1972a). The Demand For Health: A Theoretical and Empirical Investigation. NBER Books. New York, NY: Columbia University Press.

Grossman, M. (1972b, March-April). On the concept of health capital and the demand for health. Journal of Political Economy 80(2), 223-255. 
Heckman, J. J. (1988, April). Time constraints and household demand functions. In T. P. Schultz (Ed.), Research in Population Economics: A Research Annual, 1988. JAI Press.

Heckman, J. J. (2014). Private notes on Gary Becker. Discussion Paper 8200, IZA.

Hicks, J. (1939). Value and Capital: An Inquiry into Some Fundamental Principles of Economic Theory. Oxford, UK: Clarendon Press.

Juster, F. T. and F. B. Stafford (1985). Time, Goods, and Well-Being. Ann Arbor, MI: Survey Research Center, Institute for Social Research, University of Michigan. A book of research findings from the 1975-76 Time Use Survey.

Juster, F. T. and F. B. Stafford (1991). The allocation of the time: Empirical findings, behavioral models, and problems of measurement. Journal of Economic Literature 29(2), $471-522$.

Kuznets, S. (1934, June). National Income, 1929-1932. National Bureau of Economic Research. 1-12.

Lancaster, K. J. (1966, April). A new approach to consumer theory. Journal of Political Economy 74(2), 132-157.

Lancaster, K. J. (1971). Consumer Demand: A New Approach. New York: Columbia University Press.

Leibowitz, A. (1974, March/April). Home investments in children. Journal of Political Economy 82(2), S111-S131.

Long, C. (1958). The Labor Force Under Changing Income and Employment. (Gen. Ser. 65). New York: National Burea of Economic Research (distr. Princeton University Press).

Michael, R. T. (1972). The effect of education on efficiency in consumption. New York: Columbia University Press for NBER. 
Michael, R. T. (1973). Education in nonmarket production. Journal of Political Economy $81(2), 306-327$.

Michael, R. T. (1974). Education and the derived demand for children. In T. W. Schultz (Ed.), Economics of the Family: Marriage, Children, and Human Capital, pp. 120-159. Chicago, IL: University of Chicago Press.

Michael, R. T. and G. S. Becker (1973). On the new theory of consumer behavior. Swedish Journal of Economics 75(4), 378-396.

Mincer, J. (1958, August). Investment in human capital and personal income distribution. Journal of Political Economy 66(4), 281-302.

Mincer, J. (1962a, Februrary). On-the-job training: Costs, returns, and some implications. Journal of Political Economy 70(5, Part 2: Investment in Human Beings), 50-79.

Mincer, J. (1962b). Labor force participation of married women. In H. G. Lewis (Ed.), Aspects of Labor Economics. Princeton, NJ: Princeton University Press. Published for National Bureau for Economic Research.

Mincer, J. (1963). Market prices, opportunity costs, and income effects, Volume Measurement in Economics. Stanford University Press: Stanford, California. 67-82.

Mincer, J. (1974). Schooling, Experience and Earnings. New York: Columbia University Press for National Bureau of Economic Research.

Mitchell, W. (1912, June). The backward art of spending money. The American Economic Review 2(2), 269-281.

Muth, R. F. (1966, July). Household production and consumer demand functions. Econometrica 34(3), 699-708. 
National Research Council (2005). Home production. In Beyond the Market: Designing Nonmarket Accounts for the United States, pp. 55-78. Washington, DC: The National Academies Press.

Nordhaus, W. D. and J. Tobin (1973). Is growth obsolete? In M. Moss (Ed.), The Measurement of Economic and Social Performance, pp. 509-564. New York, NY: NBER Books.

Pollak, R. A. (2003). Gary Becker's contributions to family and household economics. Review of Economics of the Household 1(1), 111-141.

Pollak, R. A. (2013, June). Allocating household time: When does efficiency imply specialization? NBER Working Paper No. 19178.

Pollak, R. A. and M. L. Wachter (1975). The relevance of the household production function and its implications for the allocation of time. Journal of Political Economy 83(2), 255278.

Pollak, R. A. and T. J. Wales (1987). Specification and estimation of nonseparable twostage technologies: The Leontief CES and the Cobb-Douglas CES. Journal of Political Economy 95(2), 311-333.

Reid, M. (1934). Economics of Household Production. Wiley, New York.

Robbins, L. (1930, June). On the elasticity of demand for income in terms of effort. Economica 29(29), 123-129. Published by: Blackwell Publishing on behalf of The London.

Rosenzweig, M. R. and T. P. Schultz (1983, October). Estimating a household production function: Heterogeneity, the demand for health inputs, and their effects on birth weight. Journal of Political Economy 91(5), 723-746.

Stiglitz, J. E., A. Sen, and J.-P. Fitoussi (2009). Report of the commission on the measurement of economic performance and social progress. Technical report, Commission on the Measurement of Economic Performance and Social Progress. 
Strotz, R. H. (1957). The empirical implications of a utility tree. Econometrica 25(2), 269-280.

Viscusi, W. K. and J. E. Aldy (2003, August). The value of a statistical life: A critical review of market estimates throughout the world. Journal of Risk and Uncertainty 27(1), $5-76$.

Willis, R. J. (1973, March/April). A new approach to the economic theory of fertility behavior. Journal of Political Economy 81(2, Part 2), S14-S64. Reprinted in T.W. Schultz, (ed.), Economics of the Family: Marriage, Children and Human Capital, Chicago, IL: University of Chicago Press, 1974. 